\title{
Klasifikasi Madu Berdasarkan Jenis Lebah (Apis dorsata versus Apis mellifera) Menggunakan Spektroskopi Ultraviolet dan Kemometrika
}

\section{(Classification of Honey Based on Honeybee Types (Apis dorsata versus Apis mellifera) Using Ultraviolet Spectroscopy and Chemometrics)}

\author{
Diding Suhandy ${ }^{1 *}$, Meinilwita Yulia $^{2}$, Kusumiyati $^{3}$
}

(Diterima Mei 2020/Disetujui Juli 2020)

\begin{abstract}
ABSTRAK
Pada penelitian ini, data spektra di daerah UV digunakan bersama dengan dua metode kemometrika PCA dan SIMCA untuk mengklasifikasi madu dari dua jenis lebah yang berbeda (Apis dorsata versus Apis mellifera). Sebanyak 200 sampel madu monofloral Durian dari lebah Apis dorsata dan 120 sampel madu monofloral Kelengkeng dari lebah Apis mellifera disiapkan sebagai sampel. Data spektra diambil menggunakan parameter berikut: rentang pengukuran 200-400 nm, mode transmitansi, dan interval $1 \mathrm{~nm}$. Spektra original ditransformasi menggunakan tiga algoritma berbeda, yaitu: moving average smoothing dengan 11 segmen, standard normal variate (SNV), dan Savitzky-Golay $1^{\text {st }}$ derivative dengan 11 segmen dan 2 ordo. Hasil analisis PCA menggunakan spektra transformasi di rentang 250-400 nm menunjukkan bahwa madu Durian dan Kelengkeng dapat dipisahkan di sepanjang sumbu PC1 yang mampu menjelaskan varian data sebanyak $98 \%$. Hasil SIMCA menunjukkan bahwa semua sampel prediksi dapat diklasifikasikan secara benar sesuai dengan kelasnya masing-masing yang menghasilkan ketepatan klasifikasi sebesar $100 \%$. Beberapa panjang gelombang memiliki nilai $x$-loading tinggi, yaitu di panjang gelombang $270 \mathrm{~nm}$ dan $300 \mathrm{~nm}$. Panjang gelombang tersebut berkorelasi dengan absorbansi dari beberapa senyawa phenolic penting yang terdapat pada madu, seperti benzoic, salicylic, dan aryl-alyphatic acids. Hasil penelitian ini membuka peluang terbangunnya sistem uji keaslian madu secara mudah dan murah dengan menggunakan spektroskopi UV dan kemometrika dengan persiapan sampel yang bebas bahan kimia.
\end{abstract}

Kata kunci: Apis dorsata, Apis mellifera, SIMCA, spektroskopi UV, uji keaslian

\section{ABSTRACT}

In this research, spectral data in UV region (200-400 $\mathrm{nm}$ ) alongside PCA and SIMCA chemometrics were used to classify two types of honey obtained from different honeybees (Apis dorsata versus Apis mellifera). A total of 200 Durian monofloral honey samples from Apis dorsata and 120 samples for Longan monofloral honey from Apis mellifera were prepared. Therefore, spectral data were recorded based on the following parameters: range of acquisition 200-400 nm, transmittance mode, and interval $1 \mathrm{~nm}$. In addition, the original spectra were transformed using three different algorithms: moving average smoothing with 11 segments, standard normal variate (SNV), and Savitzky-Golay $1^{\text {st }}$ derivative with 11 segments and 2 ordos. The result of PCA using transformed spectra in the range of 250-400 nm explained the possibility of clearly separating Durian and Longan honey along the PC1 axis, with $98 \%$ variance, while the SIMCA showed a $100 \%$ proper classification rate for all prediction samples. In addition, several important wavelengths were identified alongside high x-loadings values at 270 and $300 \mathrm{~nm}$. These results were closely related to the absorbance of important phenolic compounds in honey, including benzoic, salicylic, and arylalyphatic acids. The results demonstrate a probability to establish simple and low-cost honey authentication systems, using UV spectroscopy and chemometrics on free-chemical in sample preparations.

Keywords: authentication, Apis dorsata, Apis mellifera, SIMCA, UV spectroscopy

\footnotetext{
1 Spectroscopy Research Group (SRG), Jurusan Teknik Pertanian, Fakultas Pertanian, Universitas Lampung, Jl. Prof. Dr. Soemantri Brojonegoro No.1, Bandar Lampung 35145

2 Jurusan Teknologi Pertanian, Politeknik Negeri Lampung, Jl. Soekarno Hatta No. 10 Rajabasa, Bandar Lampung 35141

3 Jurusan Agronomi, Fakultas Pertanian, Universitas Padjadjaran, Jl. Raya Bandung-Sumedang Km. 21, Jatinangor, Sumedang 45363

* Penulis Korespondensi:

Email: diding.sughandy@fp.unila.ac.id
}

\section{PENDAHULUAN}

Madu merupakan salah satu produk pertanian bernilai tinggi yang memiliki tiga manfaat sekaligus, yaitu sebagai sumber nutrisi, bahan kesehatan, dan bahan kosmetika (Oroian \& Ropciuc 2017). Secara umum, komposisi madu adalah karbohidrat $(70-80 \%$ $\mathrm{w} / \mathrm{w})$, air (10-20\% w/w), asam organik, enzim, vitamin, dan protein (Baroni et al. 2015). Menurut Pita-Calvo et al. (2017), komponen utama karbohidrat madu adalah glukosa dan fruktosa. Glukosa dan fruktosa yang tinggi pada madu berperan dalam pembentukan jembatan 
hidrogen dalam air dan menjaga kelembapan kulit yang membuat madu sangat bermanfaat di bidang kosmetika, salah satunya sebagai bahan aktif dalam perawatan kulit (Burlando \& Cornara 2013). Asam organik pada madu berkaitan erat dengan rasa madu. Protein utama madu di antaranya adalah globulin dan albumin. Madu juga banyak mengandung senyawa fitokimia atau phytochemical, seperti senyawa fenolik (asam fenolik, polifenol, antosianin, saponin, dan pigmen). Beberapa madu asal Indonesia terbukti mengandung senyawa saponin (Yelin \& Kuntadi 2019). Senyawa fitokimia ini bersifat anti-oksidan, anti-bakteri, dan anti-inflamasi atau anti-peradangan serta memengaruhi metabolisme tubuh manusia secara baik sehingga berpotensi meningkatkan kesehatan dan mencegah berbagai penyakit (Gheldof \& Engeseth 2002; Piljac-Zegarac et al. 2009). Madu juga dikenal memiliki karakteristik anti-virus, anti-parasit, antimikrob, dan anti-diabetes (Liu et al. 2013). Riset farmakologi menunjukkan bahwa kandungan bahan alami pada madu memiliki potensi untuk mengurangi risiko penyakit lambung dan kardiovaskular (AlvarezSuarez et al. 2010) dan juga memiliki manfaat untuk meningkatkan kesuburan atau fertilitas dan memperbaiki kualitas hormon yang berhubungan dengan kesuburan (Haron et al. 2014).

Secara khusus, komposisi madu sangat ditentukan oleh asal nektar madu dan jenis lebah yang menghasilkan sekresi madu (Da Silva et al. 2016). Atas dasar ini, madu dikelompokkan sebagai monofloral atau multifloral bergantung pada asal nektar madu apakah berasal dari satu jenis tanaman (monofloral) atau beberapa jenis tanaman (multifloral). Madu monofloral memiliki karakteristik organoleptik yang unik dan dianggap sebagai produk premium. Pada saat ini, permintaan pasar akan madu monofloral sangat tinggi (Park et al. 2020). Sebagai produk premium, harga madu monofloral jauh lebih tinggi dibandingkan dengan madu multifloral (Donarski et al. 2010). Selain itu, di Indonesia madu monofloral juga dikelompokkan lagi ke dalam tiga jenis bergantung pada asal lebah yang menghasilkan sekresi madu (asal entomologi), yaitu madu hutan monolforal yang dihasilkan oleh lebah Apis dorsata (MMAD), madu ternak monofloral yang dihasilkan oleh lebah Apis mellifera (MMAM) (yang dikenal juga sebagai lebah Eropa) dan madu ternak monofloral yang dihasilkan oleh lebah Apis cerana (MMAC) (yang dikenal juga sebagai lebah Asia). Secara umum, madu MMAD dan MMAC harganya bisa 3-10 kali lipat dibandingkan dengan harga madu MMAM (Soares et al. 2018; Zhang et al. 2019). Perbedaan harga ini terkait dengan keterbatasan jumlah produksi, ketersediaan, dan kesulitan panen madu MMAD dan MMAC. Dengan demikian, madu MMAD dan MMAC pada saat ini menjadi salah satu madu yang sering dipalsukan, baik dengan cara dioplos dengan madu jenis lain yang lebih murah atau pemalsuan dalam pemberian label madu hutan monofloral. Hal ini menunjukkan perlu dilakukan proses uji keaslian madu MMAD dan MMAC. Uji keaslian ini dapat memberikan manfaat baik bagi konsumen maupun bagi produsen. Bagi konsumen, adanya uji keaslian madu dapat memberikan kepastian dan jaminan mutu madu yang diperdagangkan. Bagi produsen, uji keaslian madu memberikan perlindungan atas kualitas madu yang diproduksi.

Menurut Soares et al. (2017), dari sisi objek madu yang dipalsukan maka uji keaslian madu dapat dibagi menjadi 2 bagian, yaitu uji keaslian terkait dengan produksi madu dan uji keaslian terkait asal madu. Uji keaslian madu terkait dengan produksi madu yang meliputi penambahan gula, pengolahan madu, dan penambahan air. Uji keaslian asal madu terkait organik dan bukan organik, asal botani (floral), dan asal geografis madu. Uji keaslian madu dilihat dari aspek metode yang digunakan secara garis besar dibagi menjadi dua, yaitu metode klasik dan metode modern (Chin \& Sowndhararajan 2020). Metode klasik untuk uji keaslian madu meliputi metode analisis physicochemical dan metode melissopalynological (Selvaraju et al. 2019; Puścion-Jakubik et al. 2020; ElSofany et al. 2020). Meskipun sangat akurat, metode klasik memiliki banyak kelemahan, seperti waktu analisis yang sangat lama, sangat melelahkan dan melibatkan seorang analis yang sangat ahli untuk mengidentifikasi serbuk sari setiap madu serta adanya potensi ketidakkonsistenan (Oddo \& Bogdanov 2004).

Metode modern untuk uji keaslian madu secara garis besar meliputi 5 metode, yaitu metode kromatografi, mass spectrometry (MS), infrared spectroscopy, NMR (nuclear magnetic resonance), dan teknik molekuler (Chin \& Sowndhararajan 2020). Metode kromatografi di antaranya adalah GC (gas chromatography) dan HPLC (high-performance liquid chromatography). Beberapa metode digabungkan sekaligus untuk uji keaslian madu, seperti metode GCMS untuk membedakan madu Apis cerana dan Apis mellifera (Wang et al. 2019) dan metode LC-MS untuk uji keaslian beberapa madu komersial dengan asal botani dan geografis yang berbeda (Cabanero et al. 2006). Sebagian besar metode infrared spectroscopy untuk uji keaslian madu meliputi near infrared (NIR) dan mid infrared (MIR) spectroscopy. Uji keaslian dan deteksi madu palsu pada madu asal Afrika Selatan menggunakan NIR spectroscopy dan kemometrika berhasil dilakukan dengan akurasi sebesar 93,3-99,9\% (Guelpa et al. 2017). MIR spectroscopy dan SIMCA (soft independent modelling of class analogy) digunakan untuk mendeteksi keaslian madu asal Irlandia dengan persentase ketepatan klasifikasi sebesar 90,9-100\% (Kelly et al. 2006). NMR secara luas digunakan untuk uji keaslian madu atas dasar botani dan asal geografis (Kuballa et al. 2018).Teknik molekuler, seperti PCR (polymerase chain reaction), digunakan untuk uji keaslian madu jeruk (Citrus spp.) yang dioplos dengan pemanis dari molase beras (Sobrino-Gregorio et al. 2019). Metode PCR juga telah digunakan untuk membedakan antara madu Apis cerana dan madu Apis mellifera (Soares et al. 2018). Metode modern tersebut secara umum memiliki 
beberapa kelebihan, yaitu persiapan sampel yang minimal, pengukuran yang relatif lebih cepat, dan akurasi pengukuran yang dapat diandalkan. Hanya saja hampir semua metode modern tersebut melibatkan peralatan yang relatif mahal sehingga cukup sulit diterapkan di Indonesia.

Salah satu metode spectroscopy yang layak dikembangkan di Indonesia adalah ultraviolet (UV) spectroscopy. Metode ini cukup akurat, mudah dioperasikan, persiapan sampel yang minimal, dan yang paling penting adalah spektrometernya tersedia dengan harga yang sangat terjangkau sehingga proses hilirisasi teknologinya sangat memungkinkan. Pada saat ini di Indonesia, metode spektroskopi berbasis UV spectroscopy telah diujicobakan untuk uji keaslian pangan, seperti kopi (Suhandy \& Yulia 2017; Suhandy \& Yulia 2019a) dan teh (Suhandy \& Yulia 2019b). Penelusuran pustaka menunjukkan bahwa aplikasi UV spectroscopy untuk uji keaslian madu sudah dilakukan, misalnya Roshan et al. (2013) menggunakan UV spectroscopy untuk uji keaslian madu Sidr asal Yaman. Hanya saja, penelitian tersebut menggunakan bahan kimia, yaitu ethanol untuk proses ekstraksi atau persiapan sampelnya. Untuk uji keaslian madu asal Indonesia berdasarkan asal lebahnya (entomologi) belum dilakukan. Lebih jauh, uji keaslian madu dengan proses persiapan sampel madu menggunakan air distilasi (bebas bahan kimia) belum dilakukan. Dengan demikian, tujuan penelitian ini adalah melakukan investigasi penggunaan UV spectroscopy dan kemometrika untuk klasifikasi madu berdasarkan jenis lebahnya, yaitu Apis dorsata versus Apis mellifera dengan persiapan sampel madu tanpa melibatkan bahan kimia (hanya air distilasi).

\section{METODE PENELITIAN}

\section{Sampel Madu dan Persiapannya}

Sampel madu yang digunakan adalah dua jenis madu monofloral asal Indonesia masing-masing sebanyak $2 \mathrm{~kg}$ yang terdiri atas madu ternak monofloral
Kelengkeng (Euphorbia longan) dari jenis lebah Apis mellifera dan madu hutan monofloral Durian (Durio zibethinus) dari jenis lebah Apis dorsata. Madu Kelengkeng diperoleh dari peternak madu di Kabupaten Batang, Jawa Tengah, sedangkan madu Durian diperoleh dari pengumpul madu hutan di Provinsi Jambi, seperti yang dapat dilihat di Gambar 1. Kedua jenis madu tersebut setelah diperoleh langsung dikirim ke laboratorium pada hari yang sama dan dijauhkan dari sinar matahari langsung serta disimpan pada suhu $20-25^{\circ} \mathrm{C}$ sampai tahap analisis berikutnya. Selama penyimpanan, madu mengalami kristalisasi. Sebelum digunakan sebagai sampel, madu dipanaskan menggunakan water batch pada suhu $60^{\circ} \mathrm{C}$ selama 30 menit (Frausto-Reyes et al. 2017). Sebanyak 200 sampel madu Durian dan 120 sampel madu Kelengkeng digunakan pada penelitian ini. Setiap sampel disiapkan dengan cara mencampurkan madu dan air distilasi dengan perbandingan 1:20 (v/v). Sampel madu diaduk dengan pengaduk magnetik selama 10 menit dengan kecepatan 1500 rpm (Ciblanc $^{T M}$, China) sehingga campuran dipastikan homogen. Sampel yang telah homogen ini siap diambil data spektranya.

\section{Pengambilan Spektra Sampel Madu}

Spektra sampel madu diambil menggunakan spektrometer dual beam UV-visible tipe benchtop (Genesys ${ }^{\mathrm{TM}} 10 \mathrm{~S}$ UV-Vis, Thermo Scientific, USA) dengan parameter sebagai berikut: rentang pengukuran 200-400 nm, mode transmitansi, dan interval panjang gelombang $1 \mathrm{~nm}$. Sampel madu dan referensi diambil spektranya secara bersamaan. Untuk sampel madu, sebanyak $3 \mathrm{~mL}$ madu yang telah diencerkan diteteskan ke dalam sel kuvet kuarsa (ukuran $10 \mathrm{~mm}$ ). Untuk referensi, sebanyak $3 \mathrm{~mL}$ air distilasi diteteskan ke dalam sel kuvet kuarsa (ukuran $10 \mathrm{~mm}$ ). Data spektra direkam dalam format file ekstensi .csv dan disimpan di dalam flash disk.

\section{Analisis Data}

Secara umum, fungsi metode transformasi spektra adalah memperbaiki kualitas data spektra dengan cara

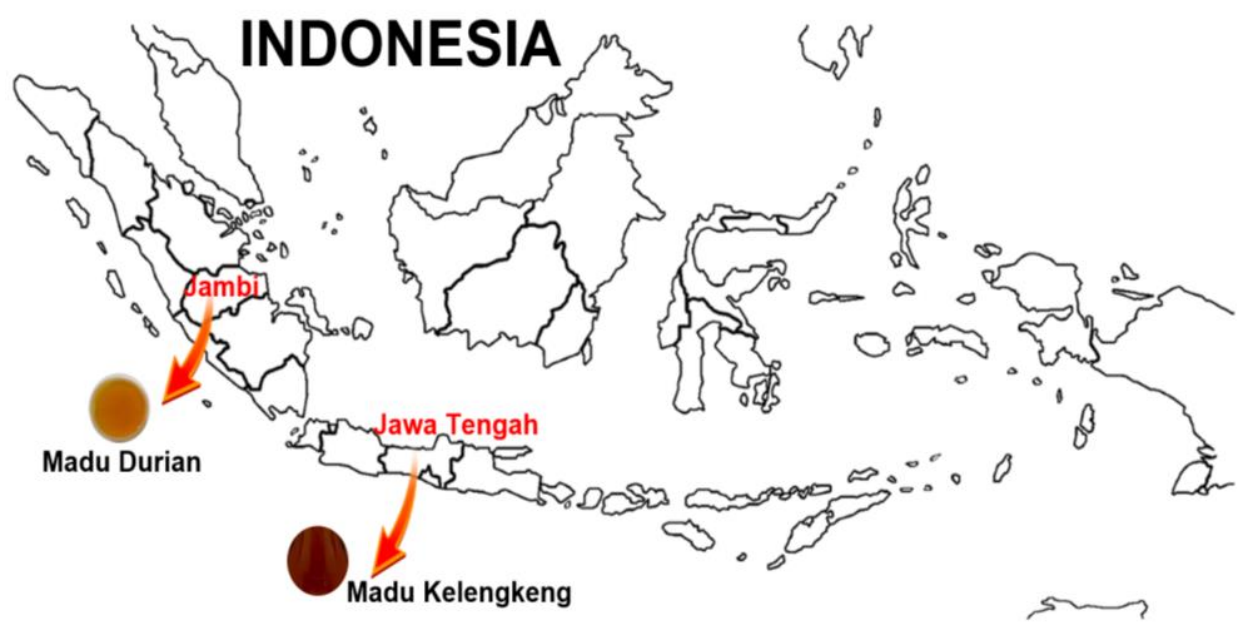

Gambar 1 Asal geografis sampel madu yang digunakan pada penelitian. 
mengeliminasi noise yang mungkin terdapat pada data spektra. UV-visible spectroscopy merupakan metode spektroskopi yang terjangkau dengan melibatkan spektrometer UV-visible yang lebih murah dibandingkan dengan spektrometer lainnya, seperti NIR (near infrared) atau FTIR (Fourier transform infrared). Hanya saja, kelemahan spektrometer UVvisible secara umum adalah memiliki nilai signal to noise ratio atau SNR yang lebih rendah. Moving average smoothing merupakan salah satu metode yang efektif untuk menghilangkan noise spektra dan meningkatkan nilai SNR (Liu et al. 2019a). Sumber noise lain yang mungkin muncul adalah efek hamburan dari perbedaan partikel dalam sistem sampel madu. Metode transformasi spektra standard normal variate (SNV) sangat efektif dalam mengeliminasi efek hamburan (scattering effect) (Liu et al. 2019a). Sumber noise lain yang mungkin muncul adalah perbedaan baseline spektra. Proses pengambilan data spektra untuk 320 sampel (madu Durian dan Kelengkeng) membutuhkan waktu yang cukup lama dan berpotensi menimbulkan perbedaan data baseline spektra. Untuk mengatasi persoalan perbedaan baseline ini maka salah satu metode transformasi spektra yang banyak digunakan adalah Savitzky-Golay $1^{\text {st }}$ derivative (Liu et al. 2019b). Berdasarkan hal tersebut maka pada penelitian ini spektra original kemudian diubah menjadi spektra transformasi dengan melibatkan tiga algoritma sekaligus, yaitu moving average smoothing (11 segmen), standard normal variate (SNV), dan Savitzky-Golay $1^{\text {st }}$ derivative (11 segmen dan 2 ordo).

Kemometrika yang digunakan adalah PCA (principal component analysis) dan SIMCA (soft independent modelling of class analogy). PCA mengubah variabel panjang gelombang yang saling berkorelasi menjadi variabel baru bernama principal component atau PC yang tidak saling berkorelasi dengan tetap mempertahankan variasi awal data (Gonzálvez \& de la Guardia 2013). Nilai PC dihitung secara iteratif sedemikian rupa sehingga nilai PC pertama (PC1) adalah yang terbesar yang membawa sebagian besar informasi dalam data (atau dalam istilah statistik: most explained variance). PC kedua (PC2) kemudian akan membawa sebagian besar informasi dari data yang tidak dibawa oleh PC1 dan seterusnya (Suhandy \& Yulia 2019c). Dua parameter statistik penting dari hasil perhitungan PCA adalah nilai Hotelling's $T^{2}$ dan Q-residuals. Keduanya biasanya dibuat plotnya secara bersamaan dalam bentuk bi-plot Hotelling's $T^{2}$ versus $Q$-residuals dan dapat digunakan sebagai salah satu metode deteksi sampel pencilan (outliers) (Šašić et al. 2018).

Metode SIMCA merupakan metode klasifikasi yang bekerja berdasarkan metode PCA. SIMCA merupakan salah satu metode klasifikasi terbimbing (supervised classification) sehingga pada SIMCA, sampel madu setiap kelas dibagi terlebih dahulu secara acak menjadi tiga bagian. Secara umum dalam analisis data spektroskopi, pembagian sampel ke dalam set kalibrasi, validasi, dan prediksi adalah sebagai berikut: jumlah sampel kalibrasi > jumlah sampel validasi > jumlah sampel prediksi. Untuk teknik pembagiannya terdapat beberapa cara seperti metode acak (random sampling) dan algoritma Kennard-Stone (KS) (Galvao et al. 2005). Pada artikel ini, proses pembagian sampel menggunakan metode acak dengan proporsi sebagai berikut: $3 / 6$ atau $50 \%$ sampel kalibrasi, $2 / 6$ atau $33,3 \%$ sampel validasi dan $1 / 6$ atau $16,7 \%$ sampel prediksi. Dengan demikian, pembagian sampel untuk kelas madu Durian adalah sebagai berikut: sampel kalibrasi (101 sampel), validasi (66 sampel), dan prediksi (33 sampel). Sementara itu, untuk kelas madu Kelengkeng, pembagian sampelnya adalah sebagai berikut: sampel kalibrasi (60 sampel), validasi (40 sampel), dan prediksi (20 sampel). Secara umum, metode SIMCA diawali dengan proses pembuatan model PCA untuk setiap kelas (kelas madu Kelengkeng dan kelas madu Durian) dalam sampel kalibrasi masing-masing kelas dan modelnya kemudian divalidasi menggunakan sampel validasi. Kemudian sampel prediksi dibandingkan dengan model kelas yang dibangun (model PCA masingmasing kelas) dan mengelompokkan sampel prediksi ke dalam kelas yang sesuai dengan analogi atau kemiripan sampel tersebut dengan sampel kalibrasi dan sampel validasi (Suhandy \& Yulia 2019c).

Hasil klasifikasi set sampel madu prediksi dievaluasi menggunakan dua pendekatan, yaitu secara visual menggunakan plot Cooman's dan secara kuantitatif menggunakan matriks konfusi dan dihitung nilai akurasi, sensitivitas, spesifisitas, dan error (Lavine 2009; Suhandy \& Yulia 2019a). Plot Cooman's adalah bi-plot dari parameter sample-to-model distances atau jarak sampel ke model dari dua buah model, yaitu model SIMCA Durian dan Kelengkeng. Di dalamnya termasuk batasan keanggotaan kelas untuk kedua model tersebut sehingga dapat melihat apakah sebuah sampel termasuk ke dalam kelas tertentu, masuk ke dalam dua kelas sekaligus atau tidak masuk ke kelas mana pun. Perhitungan matriks konfusi untuk menghitung nilai akurasi, sensitivitas, spesifisitas, dan error seperti yang dapat dilihat pada Tabel 1 (Lavine 2009).

Berdasarkan tabel matriks konfusi maka perhitungan nilai akurasi, sensitivitas, spesifisitas, dan error kemudian dilakukan menggunakan persamaan sebagai berikut (Lavine 2009; Suhandy \& Yulia 2019a):

$$
\begin{aligned}
& \text { Akurasi }(\%)=\frac{a+d}{a+b+c+d} \times 100 \\
& \text { Sensitivitas }(\%)=\frac{d}{b+d} \times 100 \\
& \text { Spesifisitas }(\%)=\frac{a}{a+c} \times 100 \\
& \text { Error }(\%)=\frac{b+c}{a+b+c+d} \times 100
\end{aligned}
$$


Tabel 1 Matriks konfusi untuk menghitung nilai akurasi, sensitivitas, spesifisitas, dan error

\begin{tabular}{lcc}
\hline & Sampel kelas madu Durian (aktual) & Sampel kelas madu Kelengkeng (aktual) \\
\hline $\begin{array}{l}\text { Sampel kelas madu Durian } \\
\text { (prediksi oleh model SIMCA) }\end{array}$ & $\mathrm{a}$ & $\mathrm{b}$ \\
$\begin{array}{l}\text { Sampel kelas madu } \\
\text { Kelengkeng (prediksi oleh } \\
\text { model SIMCA) }\end{array}$ & $\mathrm{c}$ & $\mathrm{d}$ \\
\hline
\end{tabular}

Plot modelling power ditampilkan untuk mengevaluasi struktur setiap model SIMCA yang dibangun. Modelling power menurut Barbaste et al. (2002) digunakan untuk menginvestigasi kontribusi setiap variabel (yaitu panjang gelombang) dalam setiap model SIMCA yang digunakan (dalam hal ini model SIMCA kelas madu Durian dan model SIMCA kelas madu Kelengkeng) dalam proses klasifikasi sampel madu (masuk ke dalam kelas madu Durian atau kelas madu Kelengkeng). Modelling power memiliki nilai antara 0 dan 1 dan merupakan parameter yang mendeskripsikan power setiap model secara individual (inter-class description) (Parpinello et al. 2019). Variabel dengan nilai modelling power mendekati 1 merupakan variabel yang penting dan memiliki pengaruh yang signifikan dalam model tersebut. Modelling power telah banyak digunakan oleh publikasi sebelumnya sebagai salah satu parameter untuk membantu mengidentifikasi variabel penting dalam setiap model SIMCA yang dibangun (Marini et al. 2006a; Marini et al. 2006b). Salah satu kelebihan penggunaan modelling power adalah dapat menyederhanakan model SIMCA yang dibangun dengan cara mengeliminasi variabel yang tidak penting (variabel dengan nilai modelling power kurang dari 0,3 (Canuti et al. 2018).

Semua perhitungan kemometrika (PCA dan SIMCA), termasuk transformasi spektra, dilakukan dengan bantuan perangkat lunak pengolah data multivariat The Unscrambler $X$ versi 10,4 (64-bit) (Camo Software AS, Oslo, Norwegia).

\section{HASIL DAN PEMBAHASAN}

\section{Spektra Rataan Madu dengan Dua Jenis Lebah Berbeda}

Gambar 2 merupakan spektra rataan madu dari dua jenis lebah berbeda, yaitu Apis dorsata dan Apis mellifera untuk spektra original $(A)$ dan spektra transformasi (B). Madu Apis mellifera memiliki intensitas absorbansi yang lebih tinggi dari madu Apis dorsata, baik untuk spektra original maupun spektra transformasi. Salah satu puncak pada spektra original dengan nilai absorbansi positif teridentifikasi pada panjang gelombang $280 \mathrm{~nm}$. Satu puncak pada spektra transformasi dengan nilai absorbansi positif teridentifikasi pada panjang gelombang $270 \mathrm{~nm}$. Dua puncak pada spektra transformasi dengan nilai absorbansi negatif teridentifikasi pada panjang gelombang $230 \mathrm{~nm}$ dan $300 \mathrm{~nm}$. Menurut Dimitrova et al. (2007), panjang
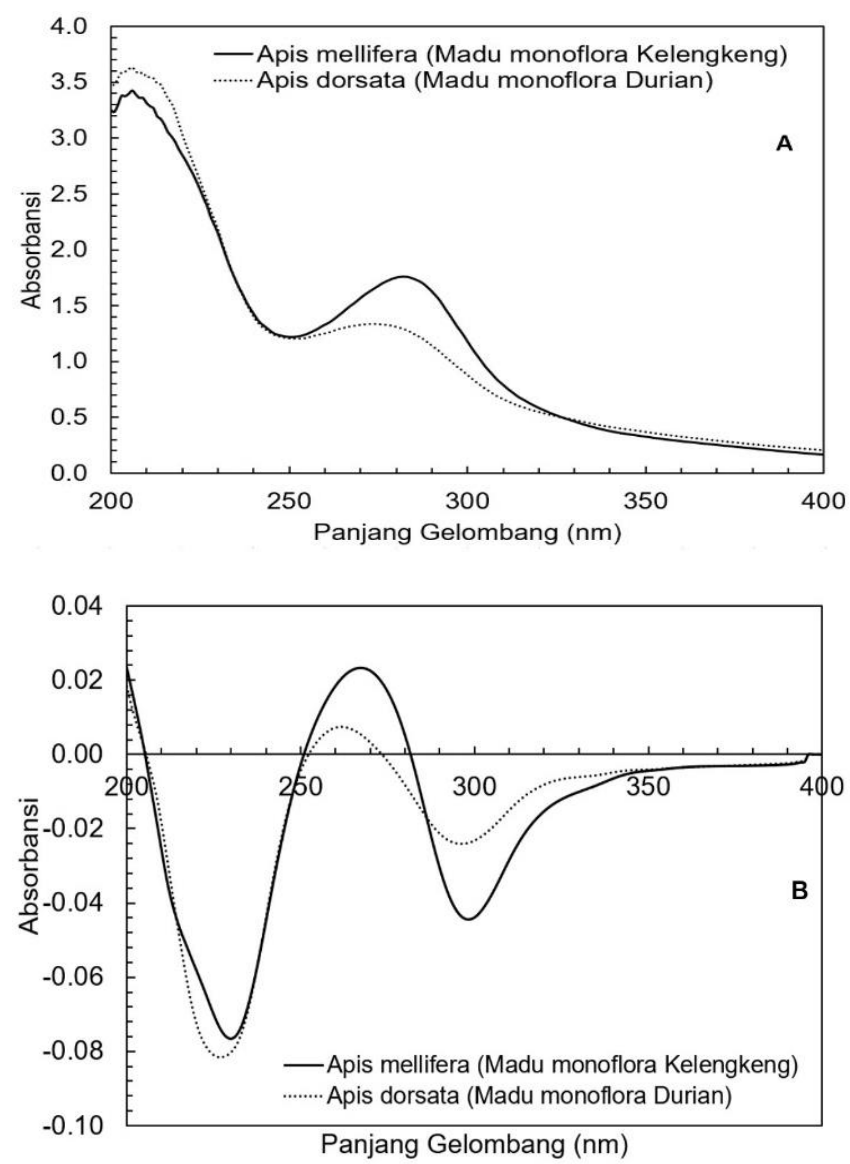

Gambar 2 A) Spektra rataan original dan transformasi dan B) Sampel madu dengan dua jenis lebah berbeda pada rentang panjang gelombang 200 $400 \mathrm{~nm}$.

gelombang 270 dan $300 \mathrm{~nm}$ berkorelasi dengan absorbansi senyawa benzoic, salicylic, dan arylalyphatic acids pada madu. Intensitas absorbansi di interval $200-250 \mathrm{~nm}$ sedikit mengandung noise atau derau spektra dengan nilai absorbansi yang sangat tinggi sehingga tidak digunakan dalam analisis berikutnya. Selanjutnya, interval $250-400 \mathrm{~nm}$ dipilih untuk perhitungan PCA dan SIMCA.

\section{Analisis PCA}

PCA dihitung menggunakan spektra transformasi pada interval 250-400 $\mathrm{nm}$ dan hasilnya dipresentasikan di Gambar 3. Gambar 3 (A) merupakan plot dua dimensi nilai skor PC1 (sumbu- $x$ ) dan PC2 (sumbu- $y$ ). Total kedua PC mampu menjelaskan variasi data awal sebanyak $100 \%$. Pemisahan sampel ke dalam dua kluster berbeda jelas terlihat di mana sampel madu Kelengkeng (Apis mellifera) berada di sebelah kiri PC1 
(negatif), yaitu $P C 1<0$. Sementara itu, sampel madu Durian (Apis dorsata) terletak di sebelah kanan PC1 (positif), yaitu PC1>0. Berdasarkan Gambar $3(A)$ terlihat ada sampel dari kluster madu Kelengkeng (diberi tanda kotak biru) yang terpisah cukup jauh dari sebagian besar sampel lainnya. Untuk mengevaluasi apakah sampel tersebut pencilan atau bukan maka dibuatlah plot Hotelling's $T^{2}$ versus Q-residuals dan dipresentasikan di Gambar 3 (B). Plot ini merupakan plot Hotelling's $T^{2}$ versus Q-residuals untuk PC1 yang bermanfaat untuk proses identifikasi sampel pencilan atau outlier. Sebuah sampel dikatakan sampel pencilan jika sampel tersebut terletak melewati garis merah putus-putus (yang dihitung dengan taraf kepercayaan 95\%) baik untuk parameter Hotelling's $T^{2}$ dan parameter $Q$-residuals. Terlihat ada dua sampel madu Kelengkeng yang saling bertumpuk (yaitu satu sampel madu Kelengkeng dari kelompok sampel kalibrasi dan satu sampel madu Kelengkeng dari kelompok sampel prediksi) yang terletak di sebelah kanan atas melewati kedua garis taraf kepercayaan $95 \%$. Sampel ini teridentifikasi sebagai sampel pencilan dan tidak dilibatkan lagi pada saat perhitungan SIMCA.

Untuk menganalisis panjang gelombang yang berkontribusi pada proses pemisahan sampel, maka
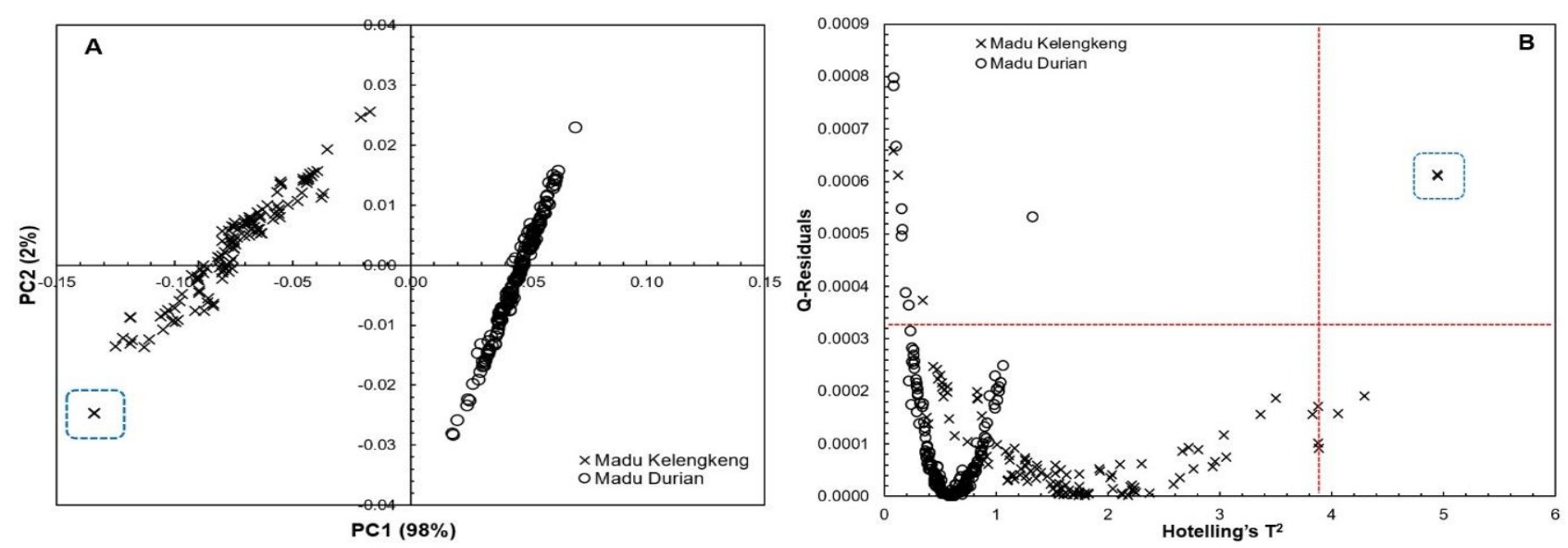

Gambar 3 A) Hasil analisis PCA: plot skor dua dimesi PC1 versus PC2 dan B) Plot Hotelling's $T^{2}$ versus Q-residuals untuk PC1. Garis merah putus-putus merupakan garis yang dihitung dengan taraf kepercayaan $95 \%$.
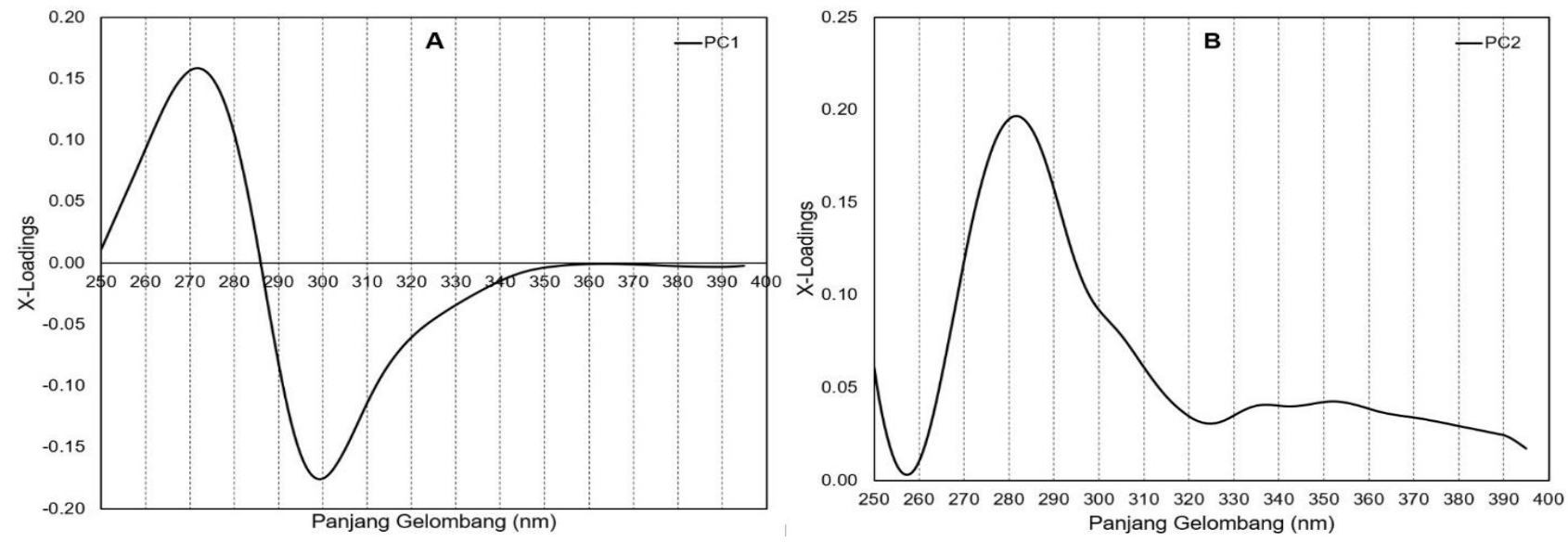

Gambar 4. Hasil analisis PCA: plot $x$-loadings untuk PC1 (A) dan plot $x$-loadings untuk PC2 (B). 
SIMCA adalah untuk kelas madu Durian yang terdiri atas: kalibrasi (101 sampel), validasi (66 sampel), dan prediksi (33 sampel). Untuk kelas madu Kelengkeng data set terdiri atas: kalibrasi (59 sampel), validasi (40 sampel), dan prediksi (19 sampel). Gambar 5 menunjukkan salah satu deskripsi luaran model SIMCA yang dinyatakan dalam bentuk bi-plot nilai skor komponen utama pertama dan kedua (PC1 dan PC2) untuk kelas madu Durian (A) dan kelas madu Kelengkeng (B).

Kualitas model SIMCA kemudian dievaluasi menggunakan set sampel prediksi. Gambar 6 (A) merupakan plot Cooman's untuk hasil prediksi SIMCA. Garis merah putus-putus merupakan batas keanggotaan atau membership (yang dihitung dengan taraf kepercayaan $95 \%$ ) untuk masing-masing kelas. Sumbu- $x$ merupakan jarak sampel prediksi ke model SIMCA untuk kelas madu Durian, sedangkan sumbu-y merupakan jarak sampel prediksi ke model SIMCA untuk kelas madu Kelengkeng. Semua sampel prediksi terkelompokkan ke dalam kelas masing-masing dengan benar, seperti terlihat di Gambar 6 (A). Tidak ada sampel yang terletak di sebelah kiri bawah menunjukkan bahwa tidak ada sampel prediksi yang masuk ke dalam dua kelas sekaligus. Akan tetapi, ada satu sampel prediksi madu Kelengkeng yang terletak di luar kedua garis merah putus-putus yang menunjukkan sampel tersebut diklasifikasikan sebagai bukan madu Durian dan madu Kelengkeng sekaligus (tidak masuk ke dalam dua kelas sekaligus). Perhitungan matriks konfusi untuk hasil klasifikasi set sampel prediksi menggunakan SIMCA dapat dilihat di Tabel 2. Hasil klasifikasi menunjukkan ketepatan klasifikasi sebesar $100 \%$ dengan nilai akurasi, sensitivitas, dan spesifisitas sebesar $100 \%$ serta error $0 \%$ untuk kelas madu Durian dan Kelengkeng.

Untuk mengetahui panjang gelombang yang memiliki kontribusi pada klasifikasi madu Durian dan madu Kelengkeng maka modelling power dari masingmasing model SIMCA untuk kelas madu Durian dan madu Kelengkeng ditampilkan seperti terlihat di Gambar 6 (B). Menurut Canuti et al. (2018), panjang gelombang dengan modelling power lebih dari 0,3 merupakan panjang gelombang yang penting dan berkontribusi pada proses klasifikasi SIMCA. Sebagian besar panjang gelombang yang berada di rentang 250 $400 \mathrm{~nm}$ memiliki nilai modelling power lebih dari 0,3, seperti terlihat di Gambar 6 (B).
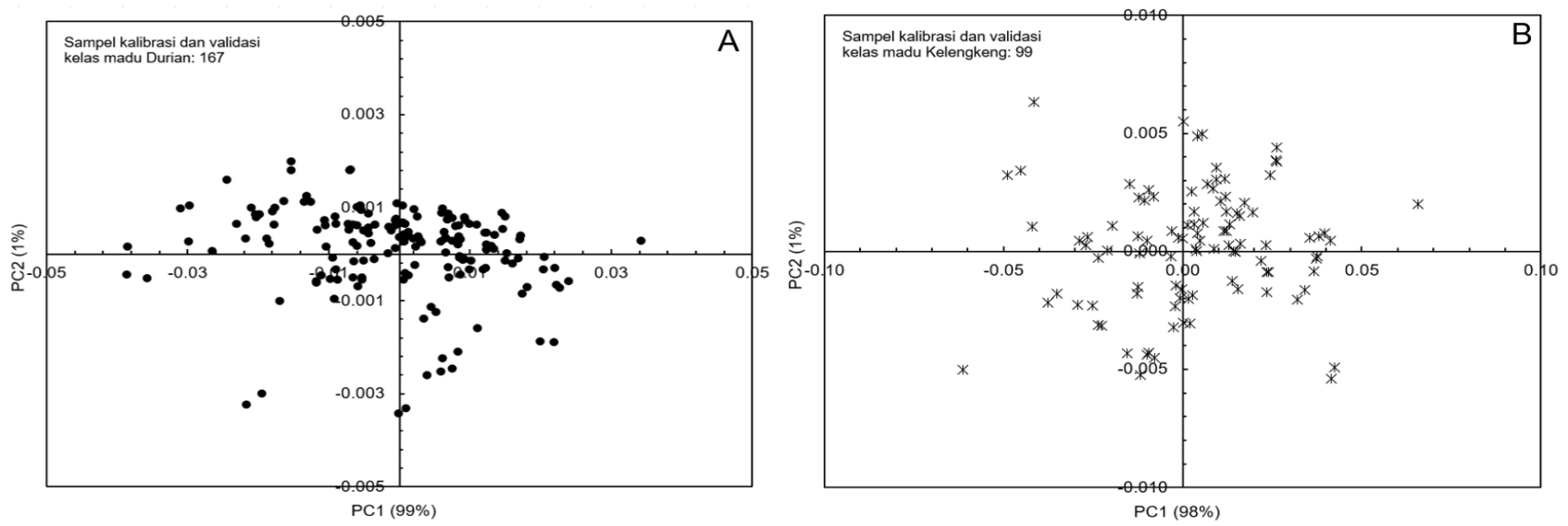

Gambar 5 A) Model SIMCA kelas madu Durian dan B) Kelas madu Kelengkeng. Dibangun menggunakan sampel kalibrasi dan validasi menggunakan spektra transformasi di interval $250-400 \mathrm{~nm}$.
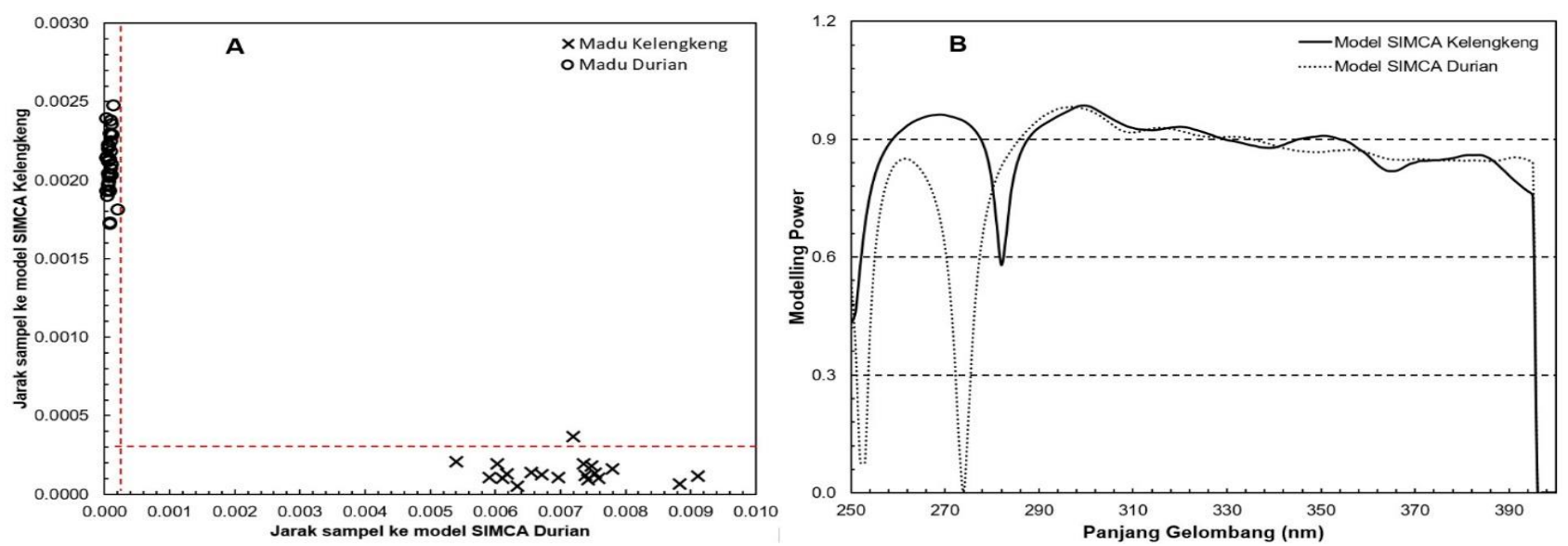

Gambar 6 Hasil SIMCA. A) Plot Cooman's untuk hasil prediksi dengan taraf kepercayaan 95\% dan B) Plot modelling power untuk model SIMCA madu Durian dan Kelengkeng. 
Tabel 2 Akurasi, sensitivitas, spesifisitas, dan error untuk hasil klasifikasi menggunakan set sampel prediksi

\begin{tabular}{lcc}
\hline & $\begin{array}{c}\text { Sampel kelas madu Durian } \\
\text { (aktual) }\end{array}$ & $\begin{array}{c}\text { Sampel kelas madu } \\
\text { Kelengkeng (aktual) }\end{array}$ \\
\hline Sampel kelas madu Durian (prediksi oleh model SIMCA) & 33 & 0 \\
Sampel kelas madu Kelengkeng (prediksi oleh model & 0 & 18 \\
SIMCA) & & $100 \%$ \\
Akurasi (\%) & $100 \%$ \\
Sensitivitas (\%) & $100 \%$ \\
Spesifisitas (\%) & $0 \%$ \\
Error (\%) & & \\
\hline
\end{tabular}

\section{KESIMPULAN}

Hasil penelitian menunjukkan bahwa UV spectroscopy dan kemometrika dengan persiapan sampel madu tanpa bahan kimia dapat diandalkan untuk mengklasifikasi madu asal Indonesia berdasarkan jenis lebahnya (entomologi). Metode kemometrika PCA dan SIMCA yang dibangun dengan menggunakan data spektra transformasi di rentang panjang gelombang 250-400 nm secara efektif dapat mengklasifikasi dua jenis madu, yaitu madu Durian dari jenis lebah Apis dorsata dan madu Kelengkeng dari jenis lebah Apis mellifera ke dalam dua kelas yang berbeda dan menghasilkan ketepatan klasifikasi sebesar $100 \%$. Proses pemisahan dan klasifikasi sampel madu Durian dan madu Kelengkeng ini berkorelasi dengan absorbansi di panjang gelombang 270 dan $300 \mathrm{~nm}$. Panjang gelombang ini berkorespondensi dengan absorbansi beberapa kandungan senyawa phenolic atau polyphenols pada madu. Hasil ini juga memperkuat dugaan senyawa phenolic sebagai salah satu penanda potensial (potential marker) untuk karakterisasi madu monofloral. Hasil penelitian ini sekaligus membuka peluang untuk melakukan penelitian lanjutan dengan pendekatan klasifikasi dengan target senyawa phenolic (targeted classification) dan melibatkan sampel madu yang lebih bervariasi baik dari sisi sumber nektarnya, seperti madu Akasia maupun dari jenis lebahnya, seperti Apis cerana.

\section{UCAPAN TERIMA KASIH}

Penulis menyampaikan ucapan terima kasih dan penghargaan kepada Kementerian Riset dan Teknologi/Badan Riset dan Inovasi Nasional yang telah memberikan bantuan pendanaan penelitian ini melalui hibah penelitian terapan 2020-2022. Penulis juga menyampaikan terima kasih kepada Jurusan Teknik Pertanian Universitas Lampung atas bantuan peralatan spektrometer ultraviolet-visible (UV-Visible).

\section{DAFTAR PUSTAKA}

Alvarez-Suarez JM, Tulipani S, Romandini S, Bertoli E, Battino M. 2010. Contribution of honey in nutrition and human health: A review. Mediterranean Journal of Nutrition and Metabolism. 3:15-23. https:// doi.org/10.1007/s12349-009-0051-6.

Barbaste M, Medina B, Sarabia L, Ortiz MC, PérezTrujillo JP. 2002. Analysis and comparison of SIMCA models for denominations of origin of wines from de Canary Islands (Spain) builds by means of their trace and ultratrace metals content. Analytica Chimica Acta. 472(1-2): 161-174. https:// doi:10.1016/s0003-2670(02)00979-0.

Baroni MV, Podio NS, Badini RG, Inga M, Ostera HA, Cagnoni M, Gautier E, Peral-García P, Hoogewerff J, Wunderlin DA. 2015. Linking soil, water, and honey composition to assess the geographical origin of argentinean honey by multielemental and isotopic analyses. Journal of Agricultural and Food Chemistry. 63(18): 4638-4645. https://doi:10.1021/ jf5060112.

Burlando B, Cornara L. 2013. Honey in dermatology and skin care: a review. Journal of Cosmetic Dermatology. 12(4): 306-313. https://doi:10.1111/ jocd.12058.

Cabañero Al, Recio JL, Rupérez M. 2006. Liquid chromatography coupled to isotope ratio mass spectrometry: A new perspective on honey adulteration detection. Journal of Agricultural and Food Chemistry. 54(26): 9719-9727. https:// doi:10.1021/jf062067x.

Canuti V, Puccioni S, Storchi P, Zanoni B, Picchi M, Bertuccioli M. 2018. Enological eligibility of grape clones based on the SIMCA method: the case of the sangiovese cultivar from Tuscany. Italian Journal of Food Science. 30(1): 184-199. https:// doi.org/10.14674/IJFS-1020.

Chin NL, Sowndhararajan K. 2020. A review on analytical methods for honey classification, identification and authentication. In: Toledo VAA, Chambo EDD, editor. Honey analysis-new advances and challenges. UK: Intechopen. https:// doi.10.5772/intechopen.90232.

Da Silva PM, Gauche C, Gonzaga LV, Costa ACO, Fett R. 2016. Honey: Chemical composition, stability and authenticity. Food Chemistry. 196: 309-323. https://doi:10.1016/j.foodchem.2015. 09.051 . 
Dimitrova B, Gevrenova R, Anklam E. 2007. Analysis of phenolic acids in honeys of different floral origin by solid-pase extraction and high-performance liquid chromatography. Phytochemical Analysis. 18(1): 24-32. https://doi:10.1002/pca.948.

Donarski JA, Jones SA, Harrison $M$, Driffield $M$, Charlton AJ. 2010. Identification of botanical biomarkers found in Corsican honey. Food Chemistry. 118: 987-994. https://doi.org/10.1016/ j.foodchem.2008.10.033.

El-Sofany A, Naggar YA, Naiem E, Giesy JP, Seif A. 2020. Authentication of the botanical and geographic origin of Egyptian honey using pollen analysis methods. Journal of Apicultural Research. 1-10. https://doi:10.1080/00218839.2020.1720950.

Frausto-Reyes C, Casillas-Peñuelas R, QuintanarStephano J, Macías-López E, Bujdud-Pérez J, Medina-Ramírez I. 2017. Spectroscopic study of honey from Apis mellifera from different regions in Mexico. Spectrochimica Acta Part A: Molecular and Biomolecular Spectroscopy. 178: 212-217. https:// doi:10.1016/j.saa.2017.02.009.

Galvao RKH, Araujo MCU, Jose GE, Pontes MJC, Silva EC, Saldanha TCB. 2005. A method for calibration and validation subset partitioning. Talanta. 67: 736-740. https://doi.org/10.1016/ j.talanta.2005.03.025.

Gheldof N, Engeseth NJ. 2002. Antioxidant capacity of honeys from various floral sources based on the determination of oxygen radical absorbance capacity and inhibition of in vitro lipoprotein oxidation in human serum samples. Journal of Agricultural and Food Chemistry. 50(10): 30503055. https://doi:10.1021/jf0114637.

Gonzálvez A, de la Guardia M. 2013. Basic chemometric tools. Comprehensive Analytical Chemistry. 60: 299-315. https://doi:10.1016/b9780-444-59562-1.00012-8.

Guelpa A, Marini F, du Plessis A, Slabbert R, Manley M. 2017. Verification of authenticity and fraud detection in South African honey using NIR spectroscopy. Food Control. 73: 1388-1396. https://doi:10.1016/j.foodcont.2016.11.002.

Haron MN, Rahman WFWA, Sulaiman SA, Mohamed M. 2014. Tualang honey ameliorates restraint stress induced impaired pregnancy outcomes in rats. European Journal of Integrative Medicine. 6(6): 657-663. https://doi.org/10.1016/j.eujim.2014. 07.001.

Kelly JD, Petisco C, Downey G. 2006. Application of fourier transform midinfrared spectroscopy to the discrimination between irish artisanal honey and such honey adulterated with various sugar syrups. Journal of Agricultural and Food Chemistry. 54(17): 6166-6171. https://doi:10.1021/jf0613785.
Kuballa T, Brunner TS, Thongpanchang T, Walch SG, Lachenmeier DW. 2018. Application of NMR for authentication of honey, beer and spices. Current Opinion in Food Science. 19: 57-62. https:// doi:10.1016/j.cofs.2018.01.007.

Lavine BK. 2009. Validation of classifiers. In: Walczak B, Tauler R, Brown S (eds), Comprehensive Chemometrics, vol. 3, Elsevier, Oxford, pp. 587599. https://doi.org/10.1016/B978-044452701-1.00 027-2.

Liu P, Wang J, Li Q, Gao J, Tan X, Bian X. 2019a. Rapid identification and quantification of Panax notoginseng with its adulterants by near infrared spectroscopy combined with chemometrics. Spectrochimica Acta Part A: Molecular and Biomolecular Spectroscopy. 206: 23-30. https:// doi.org/10.1016/j.saa.2018.07.094.

Liu J, Han J, Chen X, Shi L, Zhang L. 2019b. Nondestructive detection of rape leaf chlorophyll level based on Vis-NIR spectroscopy. Spectrochimica Acta Part A: Molecular and Biomolecular Spectroscopy. 222: 117202. https:// doi:10.1016/j.saa.2019.117202.

Liu JR, Ye YL, Lin TY, Wang YW, Peng CC. 2013. Effect of floral sources on the antioxidant, antimicrobial, and antiinflammatory activities of honeys in Taiwan. Food Chemistry. 139(1-4): 938943. https://doi:10.1016/j.foodchem.2013.02.015.

Marini $F$, Magrì $A L$, Bucci R, Balestrieri F, Marini $D$. 2006a. Class-modeling techniques in the authentication of Italian oils from Sicily with a Protected Denomination of Origin (PDO). Chemometrics and Intelligent Laboratory Systems. 80(1): 140-149. https://doi:10.1016/j.chemolab. 2005.05.002.

Marini F, Bucci R, Magrì AL, Magrì AD. 2006b. Authentication of Italian CDO wines by classmodeling techniques. Chemometrics and Intelligent Laboratory Systems. 84(1-2): 164-171. https:// doi:10.1016/j.chemolab.2006.04.017.

Moniruzzaman M, Yung An C, Rao PV, Hawlader MNI, Azlan SABM, Sulaiman SA, Gan SH. 2014. Identification of phenolic acids and flavonoids in monofloral honey from bangladesh by high performance liquid chromatography: determination of antioxidant capacity. BioMed Research International. 2014: 1-11. https://doi:10.1155/2014/ 737490 .

Oddo LP, Bogdanov S. 2004. Determination of honey botanical origin: problems and issues. Apidologie. 35: S2-S3. https://doi:10.1051/apido:2004044.

Oroian M, Ropciuc S. 2017. Honey authentication based on physicochemical parameters and phenolic compounds. Computers and Electronics in Agriculture. 138: 148-156. https://doi:10.1016/ j.compag.2017.04.020. 
Park SH, Kim YK, Kim MS, Lee SH. 2020. Antioxidant and antibacterial properties of hovenia (hovenia dulcis) monofloral honey produced in South Korea. Food Science of Animal Resources. 40(2): 221230. https://doi:10.5851/kosfa.2020.e6.

Parpinello GP, Ricci A, Arapitsas P, Curioni A, Moio L, Riosegade S, Ugliano M, Versari A. 2019. Multivariate characterization of Italian monovarietal red wines using MIR spectroscopy. OENO One. 53(4): 741-751. https://doi.org/10.20870/oenoone.2019.53.4.2558.

Piljac-Zegarac J, Stipcevic T, Belšcak A. 2009. Antioxidant properties and phenolic content of different floral origin honeys. Journal of ApiProduct and ApiMedical Science. 1(2): 43-50. https:// doi:10.3896/IBRA.4.01.2.04.

Pita-Calvo C, Guerra-Rodríguez ME, Vázquez M. 2017. Analytical methods used in the quality control of honey. Journal of Agricultural and Food Chemistry. 65(4): 690-703. https://doi:10.1021/ acs.jafc.6b04776.

Puścion-Jakubik A, Socha K, Borawska MH. 2020. Comparative study of labelled bee honey from Poland and the result of the melissopalynological analysis. Journal of Apicultural Research. 59(5): 928-938

https://doi:10.1080/00218839.2020.1726035.

Pyrzynska K, Biesaga M. 2009. Analysis of phenolic acids and flavonoids in honey. TrAC Trends in Analytical Chemistry. 28(7): 893-902. https:// doi:10.1016/j.trac.2009.03.015.

Roshan A-RA, Gad HA, El-Ahmady SH, Khanbash MS, Abou-Shoer MI, Al-Azizi MM. 2013. Authentication of monofloral yemeni sidr honey using ultraviolet spectroscopy and chemometric analysis. Journal of Agricultural and Food Chemistry. 61(32): 77227729. https://doi:10.1021/jf402280y.

Šašić S, Gilkison A, Henson M. 2018. Multivariate modeling of diffuse reflectance infrared fourier transform (DRIFT) spectra of mixtures with lowcontent polymorphic impurities with analysis of outliers. International Journal of Pharmaceutics. 536(1): 251-260. https://doi:10.1016/j.jpharm. 2017.11.058.

Selvaraju K, Vikram $P$, Soon JM, Krishnan KT, Mohammed A. 2019. Melissopalynological, physicochemical and antioxidant properties of honey from West Coast of Malaysia. Journal of Food Science and Technology. 56: 2508-2521. https://doi.org/10.1007/s13197-019-03728-3.

Soares S, Amaral JS, Oliveira MBPP, Mafra I. 2017. A comprehensive review on the main honey authentication issues: production and origin. Comprehensive Reviews in Food Science and Food Safety. 16(5): 1072-1100. https://doi:10.1111/ 1541-4337.12278.

Soares S, Grazina L, Mafra I, Costa J, Pinto MA, Duc HP, Oliveira MBPP, Amaral JS. 2018. Novel diagnostic tools for Asian (Apis cerana) and European (Apis mellifera) honey authentication. Food Research International. 105: 686-693. https://doi:10.1016/j.foodres.2017.11.081.

Sobrino-Gregorio L, Vilanova S, Prohens J, Escriche I. 2019. Detection of honey adulteration by conventional and real-time PCR. Food Control. 95: 57-62. https://doi:10.1016/j.foodcont.2018.07.037.

Suhandy D, Yulia M. 2017. Peaberry coffee discrimination using UV-visible spectroscopy combined with SIMCA and PLS-DA. International Journal of Food Properties. 20(sup1): S331-S339. https://doi:10.1080/10942912.2017.1296861.

Suhandy D, Yulia M. 2019a. Klasifikasi kopi bubuk spesialti Kalosi dan Toraja menggunakan uv-visible spectroscopy dan metode PLS-DA. Jurnal IImu Pertanian Indonesia. 24(1): 73-81. https://doi.org/ 10.18343/jipi.24.1.73.

Suhandy D, Yulia M. 2019b. Potential application of UV-visible spectroscopy and PLS-DA method to discriminate Indonesian CTC black tea according to grade levels. IOP Conference Series: Earth Environmental Science. 258: 012042. https:// doi.org/10.1088/1755-1315/258/1/012042.

Suhandy D, Yulia M. 2019c. Tutorial Analisis Data Spektra Menggunakan The Unscrambler. Yogyakarta (ID): Graha IImu.

Wang X, Rogers KM, Li Y, Yang S, Chen L, Zhou J. 2019. Untargeted and targeted discrimination of honey collected by apis cerana and apis mellifera based on volatiles using HS-GC-IMS and HSSPME-GC-MS. Journal of Agricultural and Food Chemistry. 67(43): 12144-12152. https:// doi:10.1021/acs.jafc.9b04438.

Yelin A, Kuntadi. 2019. Phytochemical identification of honey from several regions in Java and Sumbawa. AIP Conference Proceedings. 2120: 080024 https://doi.org/10.1063/1.5115762.

Zhang Y-Z, Chen Y-F, Wu Y-Q, Si J-J, Zhang C-P, Zheng H-Q, Hu F-L. 2019. Discrimination of the entomological origin of honey according to the secretions of the bee (Apis cerana or Apis mellifera). Food Research International. 116: 362369. https://doi:10.1016/j.foodres.2018.08.049. 